\title{
Bodies in motion: spaces, emotions and representations that $(\mathrm{de})$ construct realities
}

\section{Corpos em trânsito: espaços, emoções e representações que (des)constroem realidades Cuerpos en tránsito: espacios, emociones y representaciones que (des)construyen realidades}

\author{
Jaime Alonso Caravaca-Morera ${ }^{1}$, Maria Itayra Padilha²
}

How to cite this article:

Caravaca-Morera JA, Padilha MI. Bodies in motion: spaces, emotions and representations that (de)construct realities. Rev Esc Enferm USP. 2017;51:e03203. DOI: http://dx.doi.org/10.1590/S1980-220X2016036103203

${ }^{1}$ Universidade da Costa Rica, San José, Costa Rica.

${ }^{2}$ Universidade Federal de Santa Catarina, Departamento de Enfermagem,

Florianópolis, SC, Brazil.

\begin{abstract}
Objective: To analyze the social representations of the body among Brazilian and Costa Rican transsexual people through their life stories. Method: Qualitative and descriptive multicenter research. The study population consisted of 70 participants. Two organizations cooperated to collect the information, one in Florianópolis, SC-Brazil and one in San José, the capital of Costa Rica. Content Analysis was used to analyze the data. Results: Based on the results, a single social representation of corporeality was unveiled: "Modeled bodies: about the elasticity of corporeality". This representation described two clear elementary context units (discourse matrices). The first associates the body with an inconclusive, transitory, volatile, pliable, moldable and fluid object, while the second relates the body with a separate institution, but regulated and controlled by others. Conclusion: In conclusion, the transsexual body is a volatile, transient, transformable institution, crossed by the marks of a historicizing and historicizable time, which comes within the scope not only of what can be named by means of linguistic signs, but also of what belongs to the unnamable in terms of sociocultural perceptions and feelings.
\end{abstract}

\section{DESCRIPTORS}

Transsexualism; Body Image; Public Health Nursing; Psychology, Social. 


\section{INTRODUCTION}

Before introducing the theme of this manuscript, the following questions should be raised: What is a body? Is the sphere of the body immersed in the natural order or culture? Other intriguing questions are: Are the bodies constructs molded by the different social determinants or are material data (irremediably) granted by a (super)natural divinity?

In that sense, the inquiries could take other directions, beyond the randomness that makes us write on the intensity of the social representations of the body among transsexuals in two hubs on the American continent.

Therefore, it is important to highlight that, through our experience as researchers in this academic adventure, we start to think that we have a body, but that we also are a body, that is, we are the body we live in. Hence, we assert that the body is more than a given fact of reality, it is presence and an experience lived, as it is socioculturally constructed. In that sense, by possessing a body, we also produce it.

In this paradigmatic view, the body seems to be a field the modern rationalization has thingified, as it constitutes an object of power and knowledge through different technologies and devices intertwined in the different layers of the social tissue. Therefore, we believe that it turns into a field of forces that are both active and reactive.

Considered from the start as singular in relation to other physical and symbolic structures, we would like to think that the body is not simply a biological fact of our presence in the world, but a vision, an objective, a point of arrival (and departure) of the forces that shape life.

In fact, we agree with some authors who argue that the body is an experience that circulates beyond the borders of the anatomical; as it also serves as a cultural category, through which we can identify a certain worldview in a specific historical society because, at the end, the culture (of the body) constitutes a significant key that speaks to us about a certain society in a certain age $\mathrm{e}^{(1-3)}$.

In other words, we consider that the body is a human construction on an element of nature, which society models continuously. In our opinion, its propositions rest on and circulate inside a broader epistemological field that is difficult to materialize in the contemporary social imaginary.

In line with that premise, we believe that it turned into an object of social rationalization over the years - a process that has been expressed through a complex and multiple range of bio/necropolitical practices that tend to covertly control and normalize the populations, with a view to taming the bodies politically and making them economically profitable $e^{(4-5)}$.

That is the (un)timely scenario for this text, which is intended to analyze the social representations of the body as attributed by Brazilian and Costa Rican transsexuals (people who self-identify as transsexuals within the generic spectrum) through their life stories - and to identify how they are also nourished by the social constructions and promote tensions that (re)design the imaginaries of a bodily esthetics.

\section{METHOD}

This text is intended to analyze the dialogical processes of intra/inter/trans-subjective confirmation in which the social representations of the body are performed, based on some current social parameters, in which the images and certain other structures that constitute (or destitute) the transsexual in his/her environment.

Thus, this is a qualitative, socio-historical research based on the theoretical paradigm of the social representations $s^{(6-7)}$ and the complete life story as a data collection technique. The data were collected in 2014-2015 using a semistructured interview script, which was translated from Portuguese to Spanish and then subject to linguistic and semantic assessment through two pilot-interviews, held in São José (Costa Rica) in February 2015.

As a complement to the interview, the free drawing technique was used, which involved asking the participant to freely draw using some color markers, after mentioning out loud the trigger word "body".

The study population consisted of 70 transsexual participants: 60 transsexual women (individuals who were assigned male at birth and who self-identify with the female gender) and 10 transsexual men (people who were assigned female at birth and who self-identify with the male gender) from two intentionally chosen countries: 35 Brazilian and 35 Costa Rican, thus including transsexuals from Central America and South America, as well as the two main languages in the region: Portuguese and Spanish.

To develop this research, two non-governmental organizations cooperated: the Associação em Defesa dos Direitos Humanos com enfoque na Sexualidade (ADEH - Association in Defense of Human Rights with a focus on Sexuality)) and the Asociación de Apoyo a la Población Trans (TransVida - Support Association for the Transsexual Population); the first is located in Florianópolis, the state capital of Santa Catarina, Brazil, and the second in San José, the capital of Costa Rica.

To select the participants, the snowball technique was used, in which initial participants affiliated with the abovementioned institutions appointed new possible participants (peers) who could contribute to the research problem, thus constituting a network of indications.

In Brazil, the study population was exclusively restricted to people living in the state of Santa Catarina. In Costa Rica, the population included people from the seven provinces of the nation, as some difficulties existed to locate participants who lived exclusively in San José.

In the latter countries, out of fear of daily exposure, and mainly because most trans women were sex workers active at night, this negatively affected the interviews, which took place during the day or at lunchtime.

The following inclusion criteria were used: being over 18 years of age, living and being legally registered in these two countries, who considered themselves transsexuals (both transwomen and -men), who were at the start, middle or end of the transition process, or who did not want any physical change, but struggled to claim the use of their name and social pronoun. Only intersexual participants were excluded (people in conditions of genital ambiguity according to anatomical, histological and/or cytological criteria at birth).

The project was submitted to the Ethics Committee for Research involving Human Beings at UFSC, in compliance 
with National Health Council Decree 466/2012, in view of Resolution 875.931/2014. To guarantee the participants' anonymity, the interviews were identified by the terms transman and transwoman, followed by an Arabic numeral, the country of origin and the year of the interview.

The participants chose the interview date and place $a$ priori. With the participants' authorization, granted by signing the translated Informed Consent Terms, their statements were recorded using a portable multifunction digital recorder and later transcribed/transcreated for the sake of analysis.

In addition, two focus groups were held with ten participants to assess/verify whether the background information analyses were conducted appropriately and to confirm cultural and semantic expressions that may not have been fully understood during any of the interviews.

To guarantee the rigor of the analysis used in this research, enrich the reading of the collected data and critically understand the sense and meaning of the dialogues the participants shared, we departed from the premises of content analysis.

Thus, in the first phase of the pre-analysis, we systemized and organized the collected material to make it more functional. At the same time, the material was subject to exhaustive and dynamic reading and skimming to dive into the context of the statements and the contents the participants expressed. Next, we separated the documents for analysis according to the preset objectives and highlighted the relevant indicators and repeated elements in the testimonies.

In the second phase, we explored the material by detailing and refining the data that contributed to the diagnosis and tacit and strict grounding of the representations exposed. In this phase, we identified the units of meaning that would a posteriori facilitate the definition of categories and the formulation of the final corpus of social representations of the body analyzed.

Finally, in the third phase, we discussed and interpreted the actual results. In this phase, we highlighted and condensed the information and testimonies for the sake of an inferential interpretation and a critical-reflexive analysis of what was expressed in the testimonies related to common sake with a view to the construction of the social representations of the body. Therefore, we elaborated preliminary subcategories that later originated the category: Modeled bodies: about the elasticity of corporeality.

On the other hand, to analyze the drawings of the participants' free associations, they were summarized in a matrix, divided in topics according to the main meanings their drawings represented. Hence, a code was designated to each interviewee in the form of transman or transwoman, followed by the country of origin and an Arabic numerical, so that each association could be related with an interview during the final content analysis that guided the process ${ }^{(8)}$.

Thus, overall, the methodological strategies used favored the concise identification of the transsexual body's multicenter representation and expressed the complexity of the spaces and emotions their corporealities rest on.

\section{RESULTS}

When considering the analysis to characterize the social representation of the transsexual body - and after developing the organizational analysis -, a single social representation of corporeality could be unveiled, denominated: Modeled bodies: about the elasticity of corporeality.

This representation described two clear elementary context units (discourse matrices). The first associated the body with an inconclusive, transitory, volatile, pliable, moldable and fluid object:

My body is not perfect, it is unfinished thus far, there is a lot left to model, there is a lot left to show (Transwoman 9, Costa Rica, 2015 - authors' translation).

The second discursive matrix, on the other hand, related the body with a separate institution, but regulated and controlled by others: (...) My body is a stranger, I live in it, but I'm not in control because the other people dictate how it should be and how it should behave (Transman 3, Costa Rica, 2015, focus group - authors' translation).

Therefore, (in most cases) the body should be transformed, being considered a means that facilitates the social and cultural adaptation: I use the hormone to accept myself and be accepted by others (Transwoman 4, Brazil, 2014).

When discussing the first elementary context unit to characterize the representation of the body linked to an inconclusive and constantly changing structure (whether due to the different esthetic technologies, surgeries or hormone use), elements were found that are associated with the concepts of transience, incoherence, pliability, movement, desires, plasticity, metaphors/comparisons with clay and play dough, fluidness, transformation, volatility, incoherence, complexity and instability, as demonstrated next:
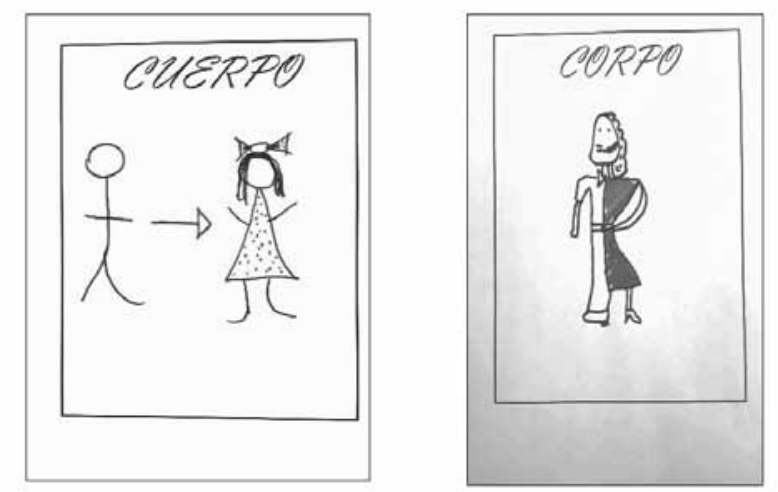

Source: Authors' personal files.

Figure 1 - Free association drawings with the trigger word "Body", associated with the concepts of transition and transformation of the participants Costa Rican transwoman 2 and Brazilian transwoman 35 - San José, Costa Rica, 2015.

I never liked this one I was born with (referring to her own body), I never was a man; it was all a mistake of nature. That is why one day, I decided to buy a scalpel, I bought dental anesthesia, I researched on the Internet what we should do to stop producing testosterone and I also investigated how to pull my testicles from my body, because I really did not want to keep on producing more testosterone and I wanted to stop taking that much hormone because it was negatively affecting some things. I always knew the body could be changed, isn't that what plastic surgeons do? So I studied on the Internet for three months, I was that desperate that I thought I was a doctor and committed this 
stupid mistake, I started to make a small incision there in the middle of the sack and started cutting to get these damn testicles off which I considered to be the testosterone factory and I really didn't want them inside me (Transwoman 25, Brazil, 2014).

I really felt unsatisfied with this body I received, God made a mistake, he wanted to play with me. This body is not mine, it does not belong to me, that's why suicide has lived with me my entire life, I was born in a wrong body, I was never a woman, I have always been a man, except that my body could never understand that, that's why I prayed every day that this whole tragedy would end the next day (...) I didn't want to get "monstruated" anymore, I didn't want boobs anymore, I wanted to have a male body with a beard and lots of body hair (...) but that never happened (Transman 8, Costa Rica, 2015).

One noteworthy point in the above statement is the word "monstruated", which the participant used to refer to the menstruation process. This expression is loaded with a semantic meaning associated with pain, non-acceptance and rejection as, in his words, the menstruation issued a mortifying message, which reminded him of the trauma of his bodily non-conformity.

On the other hand and in addition, in the life stories and drawings, the interactive strategies were expressed that were accomplished through different transformation technologies (surgeries, hormone use, industrial silicone injection) that make the body reveal its pliability, as confirmed next:

\section{ABOUt THE PLIABILITY OF THE BODIES:}

(...) I've told you so, we are all born as blank sheets, where you write what you want, we are born unfinished, incomplete, that's how I see it, God gives you the chance to do what you want with that sheet, you can transform your body as you want, you can even turn it inside out if you want to (Transwoman 7, Costa Rica, 2015).

The body gives me the feeling of being an endless product (...) you do this today, that tomorrow, you can mold it as you want, don't you like your nose? So do it differently; you don't like your belly? So have a lipo (Transman 11, Brazil, 2014).

My body is movement, it moves, it has a start but not an end, it moves according to my dreams, it is not closed, nothing is closed in this life, (...) to give an example, if you want you can inject yourself more silicone, get rid of the fat, take more pills (hormone), etc. (Transwoman 28, Costa Rica, 2015).

The body is something very crazy, you can do what you want with it, now more than ever, because technology is highly advanced (Transman 11, Brazil, 2014).

According to the testimonies shown earlier, the transsexual body is characterized by ambivalence: on the one hand, it is equivalent to a threatened space (its probable elimination or mutilation is noted, through the compressive home, medical and cisnormative statutes) but also functions as possible insurgence in view of the capitalist/post-colonial alienation: it turns into a productive instance of materiality, spaces and meanings; into a point of departure and destination.

When considering the second elementary context unit that characterizes the body as a separate institution, but regulated and controlled by the others, elements were found that are associated with the concepts of non-acceptance, desire/need to be accepted, fit in, protection and shields, as demonstrated next:

\section{BODY AS AN INSTRUMENT TO ACCEPT MYSELF AND BE ACCEPTED BY OTHERS}

Everything I do to change my body is to please others, I never wanted to have big boobs, small ones would have been enough (...) I have done everything I can to please the others (...) I have put my life at risk to be accepted in my neighborbood (...) my opinion in this society does not matter (Transwoman 12, Costa Rica 2015).

Everything I have done is for the others, all changes are in accordance with what the others find beautiful or think I should do, I am one of the people who think you don't need to have a body with a female silhouette to be a woman, I could be a woman with a beard, grave voice and no boobs, but I put all that for others to accept me more easily (Transwoman 28, Brazil, 2014).

I gradually noticed, when I got to Floripa, that I should do and act like the transsexuals here did and, at the time, I recall that being blonde and having straight hair was fashionable, so imagine, me, a brunette with curly hair, I looked horrible blond with my hair forcibly straightened with a flat iron, it was horrible (...) but I did all that so as not to differ much. (Transwoman 8, Brazil, 2014)

That was when I realized that I couldn't be the woman I wanted to be, I had to act like the rest of the submissive chicks acted and let myself be treated me as they treated them, I couldn't be a very "macho" woman because the rest would see me as an odd species (Transwoman 18, Costa Rica, 2015).

The social representation elaborated on the complex transsexual body that changes to be accepted in a certain societal circle expresses behavioral protection codes defined by the different social interaction movements. This body is captured in its appearance, considered in its (lack of) power and (dis)located in a space of social acknowledgement.

In the same context, the statements evidence the vulnerability of the body and oblige it to take refuge behind resistant structures, frames, shells or shields. This vulnerability emerges as a result of the context that created them and as a direct consequence of infrastructural ties in the patriarchy that operated in the course of their lives.
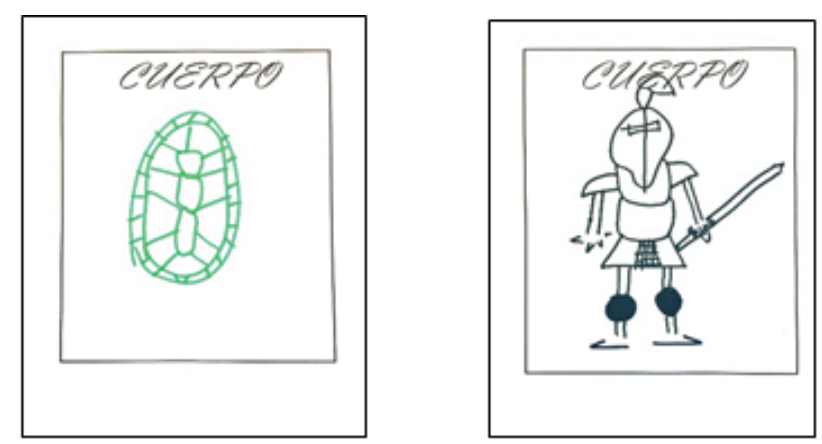

Source: Authors' personal files.

Figure 2 - Free association drawings with the trigger word "Body", associated with elements of resistance of the participants Costa Rican transwoman 31 (tortoise shell) and Costa Rican transman 10 (Armor) - San José, Costa Rica, 2015. 
Based on the skimming of the above drawings, we affirm that the transsexual body is the primary environment inhabited. This structure goes beyond the physical border that identifies it as a temporal and cultural context. On the other hand, but as a complement, in line with the analysis proposed in the second discourse matrix that characterizes the representation of the body as an institution vulnerable to the public prohibitions, some elements emerge related to struggle, resistance and continuous transformation as a product of socioculturally imposed standards.

In this sociocognitive scenario, some institutions that served as spokespersons in the objectification of the social representations can be identified in the hegemonic (generic, esthetic, political, family and moral) powers, as they legitimized their persuasive and (dis)informative role.

To put this in practice, they turned to an intentional and arbitrary use of standards, transforming them by means of technologies that linked the personal and/or group needs with a consumption object they sentenced to satisfy that need and offer the idea of a body that should be modified to be accepted, as expressed next:

Of course I don't love myself, of course I don't accept myself, I will only accept myself when I have a totally male body, that's my standard, that's my struggle, and I will continue until I get it, it doesn't matter if I have to torture my body with plenty of hormones, injections and supplements (Transman 6, Costa Rica, 2015).

I never accepted myself. That was when I started to take a hormone cocktail in pharmacies. At first it was magical to see that my body was getting so feminine (...) I wanted to be accepted (Transwoman 6, Brazil, 2014).

In parallel, the results reveal that the transsexual body is not a static or unchangeable institution, but flexible, under permanent construction, (re)configurable and transformable according to the parameters imposed by alterity. We think that, based on the social representation the participants express, the transsexual body is like an institution that inhabits places, but also produces spaces. It is a body that extends beyond the epidermis and expands the sensory capacity, in reaction to an excessively discursive or constructivist view.

\section{DISCUSSION}

Concerning the conceptions shown in the testimonies and drawings, it was clear that the elaboration processes of the social representation of the body in transsexuals and its subjective and plural becoming took shape through the act of subjection, by means of an exchange game of actions, beliefs, discourse and imaginaries, in a superficial and still patriarchal society in both realities investigated.

As observed, thinking of the transsexual body as a research object supposes the drawing of an epistemological body. In an initial approach of the theme we want to unveil, we can affirm that this body is a physical space, whose limiting (and limited) external surface hides a complex biological interiority and, at the same time, develops in the surrounding cultural environment.

In each transsexual body, fundamentally vulnerable, pliable, fleeting and damageable, life stories are lived and represented that picture the life world in which it moves, lives and interact with (many) other bodies. In this process, it specifically has feelings and words at its disposal as communication instruments, while its image (before other bodies and the own body, in the mirror) changes almost invisibly, in the course of its daily growth and development.

The transsexual body is a natural and social structure, whose behaviors gain meaning in a given temporal and territorial context. Thus, it is seen (the sight lacks intentionality) by some bodies and looked at (the look is a way of examining through the ideological crystal of who observes) by countless people with lenses that often impose incoherencies and contradictions in the body's self-perception.

Looking at the transsexual body as an object comes with many intentions: the masculinizing, feminizing, moralizing, political, artistic, fetishist, cispunitive, heteronormative, philosophical, religious and, among many others, the medical judgment.

Although, in this manuscript on the transsexual corporeality, we need to think of the body in all of these perspectives, in this analysis, we center on the reflection of the transsexual body as an object subject to the posture of domestication and political and public (de)naturalization.

From the start, we have talked about a trend to domesticate the body that is expressed in the different forms of scientific discourse: esthetic, sexuality, hygiene, nutrition, medicine and sports. The common denominator in all of these forms is its claim on (trans)forming people and fitting them into concrete ideas of modernity, as demonstrated in some (other) studies on the theme ${ }^{(9-12)}$.

When affirming this domesticating vision, we argue that the transsexual bodies function as (re)production paradigms of the specific social configurations, which promote a nonacceptance of their (self)images. It is simultaneously evidenced that the transsexual body carries endless messages: it is both a repository and creator of meanings.

This body talks through gestures with a high symbolic value; it immediately evidences the personality they envelop and, in a dialectic relationship, the linguistic figure that constitutes it is exposed through its reflection ${ }^{(2,13)}$.

We could also guarantee through the analysis of the two discursive matrices that the transsexual corporeal dimension has been (re)covered to exhibit its sociohistorical construction, in which it is fundamental to situate the social determinants that produce some corporal stylistic constructions.

In addition, it is relevant to recover the idea that the body consists of socially attributed meanings, as well as agents who express complex social logics/inconsistencies in daily events; therefore, we see the transsexual body as something that is both constituted and constituting.

In line with some studies, we should acknowledge the dynamics of the relation body-technologies-society, in which the transsexual subjects not only have their corporal individuality as a resource for action, but also construct it through interpretive strategies of adaptation to the environment, through different transformation technologies that make the body reveal its pliability ${ }^{(14-16)}$.

Aware of this paradox, we would like to raise the premise that the transsexual bodies, in their "being" as well as their 
"living" (in society), contribute to the signification of the urban and topographic spaces in our contextual reality. This assertion presupposes that the social representation shown earlier acts as a perception matrix that configures schemes of meaning of the transsexual group, based on which communal and customizable processes of signification and meaning of the reality it represents take place; not only as the assigning of a symbolic label, but also with the evaluative attribution that confronts the body with an antinomy: I should change the body according to what the others impose, with a view to fitting in and avoiding stigmatization processes.

Hence, in the representations circulating in the social discourse on the transsexual body, the esthetics and image of a transformed body triggers a range of activities in the subjects in which their modes of thinking and feeling are questioned, according to consensuses imposed by the arbitrary convention system, which express their conditions of (im)possibility and modeling.

In view of the narratives cited, the signification of the transsexual body is no longer linked merely to the idea of a transformed/disturbed body, but to a body that changes (and should change) constantly, the idea of a body susceptible to being signified and expressed as an attribute. That is, a moldable, pliable body, shapeless or easily deformable, and which transforms to fit in and can be seized/captured in the meanings of the representation found ${ }^{(15,17-18)}$.

In this exact sense, we agree with some authors who argue that, according to the operation of cis-heteronormativity, the symbolic constructs in the subjects (transsexuals here) modes of positioning that happen in time and their biographical repercussions in the bodily reality ${ }^{(16-17)}$.

In this paradigm, the "ideal" transbody - fugacious and ethereal - functions as a mechanism through which the hegemonic (cisnormative) sectors impose their cultural categories and raise the subject to the category of consumer of ideas/presumptions that colonize the basic needs and, consequently, daily life.

These identities and subjectivities allude to the construction of body styles that rise to the category of stereotypes, which are functional for the interests of the dominant groups (and the patriarchal industries) ${ }^{(19-22)}$.

In this logic/inconsistency of domination and imposition of the historically patriarchal cis-standards, the use of discursive anchorage based on the surface of the bodily stylistics means a form of negotiating with the gender standards that legitimizes the practices referenced in the discourse about the natural determination of appearance as normal.

On the other hand, but as a complement, addressing the transsexual body as a product that is modifiable to be accepted, we could create a metaphor linked to the neocapitalist conjuncture, in which we compare the body with commerce, in which it has to be turned into a preferred object of consumption, being considered as capital and simultaneously as a fetish ${ }^{(15)}$.

In fact, the importance attributed to the body and its capital and "fetishist" appearance is a cultural and social fact that changes in function of the society and the age. Therefore, we underline this close relation between the body and the social and cultural relationships and standards. In this logic/inconsistency, the body is considered as a moldable object, and beauty is definitively considered as an element that facilitates this social "fit in" within a specific context.

The (transsexual) body has clearly been used as an object and target of the necro/biopower; as an object in the sense that it has to be seen and valued as a productive instrument, demanding some exercises and maneuvers for this end, and as a target of necro/biopower. Recovering this idea, we consider that this thought introduces the idea of a transsexual body that is being affected by others and at the same time affects the others.

In this line of reasoning, being a (transsexual) body means entering an endless relation of affects and effects. Therefore, the transbody lived - this body incarnated any time -, far from being coherent and singular, is continuously moving in contradictory environments or enjoying at least partial (in)coherences.

According to the above, being/having a body means being enabled/inhabited by a universe of significant chains that join in the action of signifying something susceptible to being learned through representation.

Hence, we finish these arguments by declaring that the transbody, individual and collectively, resists and destabilizes the crystallized meanings on the urban routines, transforms the landscape and installs other images and alternative acts that permit broadening the limits of what is bodily and socially possible. It is a primary site of social and individual contestation; that is, the focal point for the oppression and, at the same time, empowerment.

\section{CONCLUSION}

In view of the ethereal nets involving the representations of the transsexual body (including the world), the frailty and pliability of the ontological being is striking, mediated and masqueraded (most of the time) by the hegemonic powers whether social, religious, racial or cisnormative - that work to close off the doors of other modes of being/possessing/ living (in) a body.

The metaphorical representation of the body (and its consequent discourse matrices) presented represents an individual attempt to attribute a code of signification that guides the meaning the bodily reality gains with regard to the temporal experience.

In that sense, the voluble, ephemeral, transformable and (un)wanted transsexual body is (always) crossed by the imprinting of a historicizing and historicizable time, inscribed not only with what can be named by means of linguistic signs, but also by what belongs to the unnamable in terms of perceptions and feelings.

The social representation of the transsexual body covered up what could not be signified but by meaning, and that is why they undermine the uncertainty that the (ir)rationality of the perishable leaves room for a shared understanding.

From a complementary perspective, this representation links the wires that constitute what is fundamentally vital and human, which is but the potential finiteness that embraces transsexuality, as a material representative of the undeniable in the context inscribed in the bodily registers. 
The arguments we present argue that the transsexual body is used as a form of expression and manifestation of the cultural experiences and failures. Hence, it is production locus of discourse in favor of and against the order of gender prohibitions.

The different discourses, categories, feelings and thoughts of the actual protagonists in this research were unified in the representation described within some temporal coordinates and shaped a symbolic, structured and structuring scheme of the body image recognized by the transsexual subject who owns it.

Finally, we should declare that the history of the body cannot be separated or dislocated from the construction devices of biopower and necropolitics because, as we mentioned at the start of the introduction, the body is a text, a socially constructed text, that is, a living file of the history of the production and reproduction process of the hegemonic sociocultural guidelines.

\section{RESUMO}

Objetivo: Analisar as representações sociais do corpo entre pessoas transexuais brasileiras e costa-riquenhas por meio das suas histórias de vida. Método: Pesquisa qualitativa, multicêntrica e descritiva. A população do estudo foi composta por 70 participantes. Contou-se com a colaboração de duas organizações, em Florianópolis, SC-Brasil e em San José, capital da Costa Rica para coletar as informações. Os dados foram analisados segundo a Análise de Conteúdo. Resultados: A partir dos resultados, desvelou-se uma única representação social associada à corporeidade: “Corpos modelados: sobre a elasticidade da corporeidade”. Esta representação descreveu duas unidades de contexto elementar (matrizes do discurso) claras. A primeira delas associa o corpo a um objeto inconcluso, transitório, volátil, maleável, moldável e fluido, enquanto a segunda relaciona o corpo com uma instituição própria, mas regulada e controlada pelos outros. Conclusão: Conclui-se que o corpo transexual é uma instituição volúvel, efêmera, transformável e atravessada pelas marcas de um tempo historizante e historizável, que se inscreve não só naquilo que pode ser nomeado diante do emprego de signos linguísticos, mas também naquilo que pertence ao registro do inominável em termos de percepções e sensações socioculturais.

\section{DESCRITORES}

Transexualismo; Imagem Corporal; Enfermagem em Saúde Pública; Psicologia Social.

\section{RESUMEN}

Objetivo: Analizar las representaciones sociales del cuerpo entre personas transexuales brasileñas y costarricenses a través de sus historias de vida. Método: Investigación cualitativa, multicéntrica y descriptiva. La población del estudio consistió en 70 participantes. Se contó con la colaboración de dos organizaciones en Florianópolis, SC, Brasil y San José, capital de Costa Rica para recopilar información. Los datos se analizaron mediante Análisis de Contenido. Resultados: A partir de los resultados, se dio a conocer una sola representación social asociada con la corporalidad, "Cuerpos modelados: la elasticidad de la corporalidad". Esta representación describió dos unidades de contexto elementales (matrices del discurso) claras. La primera asocia al cuerpo a un objeto sin terminar, transitorio, volátil, maleable, conformable y fluido, mientras que la segunda relaciona al cuerpo con una institución específica pero regulado y controlado por otros. Conclusión: Se llegó a la conclusión de que el cuerpo transexual es una institución voluble, efímera, transformable y atravesada por las marcas de un tiempo historizante e historizable, inscripto no sólo en lo que puede ser identificado en el uso de los signos lingüísticos, sino también lo que pertenece al registro de lo indecible en términos de percepciones y sensaciones socioculturales.

\section{DESCRIPTORES}

Transexualismo; Imagen Corporal; Enfermería en Salud Pública; Psicología Social.

\section{REFERENCES}

1. Pennac D. Journal d'um corps. Paris: Gallimard; 2012.

2. Drummond M. The meaning of boys' bodies in physical education. J Men's Stud. 2013;11(2):131-43.

3. Echeverría J. La revolución tecnocientífica. Madrid: Fondo de Cultura Económica; 2013.

4. Agamben G. Homo sacer: el poder soberano y la nuda vida. Valencia: Pré-Textos; 2003.

5. Foucault M. Vigilar y castigar. México: Siglo XXI; 2010.

6. Camargo BV. Um primeiro estudo histórico e conceitual do seminário "Epistemologia e representações sociais", conduzido por Serge Moscovici e Denise Jodelet em 1994. Psicol Saber Soc. 2016;5(1):5-17.

7. Caravaca-Morera JA, Padilha MI, Silva DGV, Sapag J. Aspectos teóricos e metodológicos das representações sociais. Texto Contexto Enferm. $2015 ; 24(4): 1157-65$.

8. Bardin L. Análise de conteúdo. 3ª ed. Lisboa: Edições 70; 2011.

9. Niemeyer F, Kruse MHL. Constituindo sujeitos anoréxicos: discursos da revista Capricho. Texto Contexto Enferm. 2008;17(3):457-465.

10. Ibáñez RM, Pérez ES. Cuerpos y diferencias. Madrid: Plaza y Valdés; 2013.

11. Berg M, Krich MA. Bodies on trial: performances and politics in medicine and biology. Body Soc. 2014;10(3):1-12.

12. Springgay S. Thinking through bodies: bodied encounters and the process of meaning making in an e-mail Generated Art Project. Stud Art Educ. 2015;47(1):34-50.

13. Blackman L, Eatherstone M. Re-visioning body \& society. Body Soc. 2014;16(1):1-5. 
14. Gardner RM, Brown DL. Body image assessment: a review of figural drawing scales. Pers Individ Dif. 2010;48(2):107-11.

15. Costera-Meijer I. "Which difference makes the difference? On the conceptualization of sexual difference". In: Hermsen JJ, Van Lenning A, editors. Sharing the difference: feminist debates in Holland. New York: Routledge; 2011.

16. Zabludovsky G. Bodies and affection as study objects in Latin America: thematic interests and recent process of institutionalization. Sociológica. 2011;26(74):33-78.

17. Bru J. El cuerpo como mercancía. In: Nogué J, Romeron J, editores. Las otras geografías. Valencia: Editorial Tirant lo Blanch; 2012.

18. Zafra R. Sujeto y red: potencia y limitación política del (des)hacer los cuerpos online. Cad Pagu. 2015;(44):13-30.

19. Torras M, Acedo N, editores. Encarnaciones: teoría(s) de los cuerpos. Madrid: Editorial UOC; 2008.

20. Britto D. That stupid girl nice: moldings bodies, women undergoing. Canada: Polis Network; 2015.

21. Bento B. A reinvenção do corpo: sexualidade e gênero na experiência transexual. Rio de Janeiro: Garamond; 2006.

22. Bergeron SM, Senn CY. Body image and sociocultural norms: a comparison of heterosexual and lesbian women. Psychol Women Q. 2008;22(3):385-401. 